\title{
Expansion Without Western Missionary Agency and Constructing Confessional Identities: The African Orthodox Church Between the United States, South Africa, and East Africa (1921-1940)
}

\author{
CIPRIAN BURLACIOIU \\ LUDWIG-MAXIMILIANS-UNIVERSITÄT MÜNCHEN
}

\begin{abstract}
The African Orthodox Church (AOC) is a prime example of religious globalization beyond Western missionary communication networks. This black independent church was founded in New York in 1921 and spread rapidly as far as South Africa, East Africa, and even select areas of West Africa-though not as the result of organized mission work but, rather, through reporting in African American journal publications. Typologically, the AOC belongs to Ethiopianism. Yet this church defined itself in relation to the Eastern Orthodox tradition, although initially more in an imaginary way than in a real one. This contribution on the AOC illustrates several key points for the study of world Christianity: the need of a transregional perspective, the importance of non-Western agency, the role of media for transatlantic non-Western Christian networks already back in the 1920s, the role of Eastern churches in the emerging world Christianity, the dynamic formation of denominational identities, and so on.
\end{abstract}

KEYWORDS: non-Western mission, newspapers, Afro-American religion, African Christianity, Orthodoxy

\section{The Formation of the African Orthodox Church in the United States as a Religious and Political Movement}

George Alexander McGuire ${ }^{1}$-the founder of the African Orthodox Church (AOC)-was born in 1866 in Antigua. He grew up in the Anglican Church, 
graduated in 1888 from a Moravian seminary, and served as a pastor with the Moravians in the Virgin Islands, before emigrating to the United States. In 1893 he left the West Indies for the United States, where he enrolled first with the African Methodist Episcopal Church but later pursued a career in the Episcopal Church. His work as an archdeacon among Afro-Americans in Arkansas marked him out as a capable church leader. In protest against the so-called Arkansas Plan of Bishop William Montgomery Brown, McGuire left his position in Arkansas and went to Massachusetts, where he founded a new parish in 1908 among the Afro-Caribbean community. Soon, his newly founded parish became the fastest-growing one in the diocese, but it was denied self-supporting status and consequently a deeper autonomy. Disappointed, McGuire left Massachusetts in 1911 and decided to work as a field secretary for the American Church Institute for Negroes in New York, an Anglican institution created in 1906 to contribute to improving the lives of Afro-American Episcopalians. In 1913 he went back to Antigua and worked as an Anglican pastor. Years later, McGuire reflected on his fate in the Episcopal Church in the following terms: "Our perpetual lot is to remain doorkeepers in the Holy Catholic Church with the added privilege of gathering the crumbs which fall from our masters' table," and spoke about "ecclesiastical slavery."

Soon after World War I he returned to New York having been attracted by the propaganda of Marcus Garvey. There, McGuire associated himself with the Reformed Episcopal Church, a white Protestant church founded in 1873 in New York, which was more responsive to the aspirations of black ministers. McGuire founded his own parish within this church, recruiting mainly from the Afro-Caribbean community.

In New York, McGuire came into contact with Garvey and the Universal Negro Improvement Association (UNIA). McGuire became a prominent spokesman of the organization and was elected as chaplain-general at its first general assembly in August 1920, assuming the symbolic title "Archbishop of Ethiopia." He understood his appointment as a call to organize a universal church for people with African ancestry and made plans for the proclamation of a "Church Ethiopic" at the second general assembly of the UNIA. ${ }^{3}$ Such plans were finally rejected by many UNIA activists, including Garvey, who preferred to remain affiliated to their own various churches. Consequently, McGuire was forced to step down and to abandon UNIA at its convention in August 1921.

In reaction to the rejection of his plans McGuire sought alternatives. He implemented his plan to found a universal Episcopal church beyond the bounds of the white-dominated Roman Catholic and Episcopal churches for people with African ancestry with the support of his own parish. A parish assembly declared the formation of the AOC on September 2, 1921. Lacking strong political or social support, the new church sought legitimacy in the consecration 
of McGuire as its first bishop by the self-styled "Catholic" bishop, though independent of Rome, Joseph René Vilatte, who had been formally consecrated bishop in 1892 in the Syrian Church in Colombo (Ceylon). Although Vilatte was eventually excluded from the Syrian Church at a later date, he claimed to possess apostolic succession and operated in North America and Europe as an episcopus vagans, consecrating priests and bishops and contributing to the formation of a self-styled "Catholic" network of churches, independent of Rome. The AOC activists were convinced that, following the consecration of McGuire by Vilatte, the new church possessed valid apostolic succession from Eastern sources and had become part of the universal Church of Jesus Christ. They were thoroughly convinced of the authenticity of the Vilatte succession: "Thus [Bishop McGuire] has come down to us in the most direct, unquestionable and provable line of Apostolic Succession to be found in any branch of the Western Church today.... And thus is established the irrefutable fact that the African Orthodox Church is a true, living branch of the One, Holy, Catholic, Apostolic Church of Christ."

\section{Expansion Without Western Missionary Agency: The Role of the Secular and Religious Press in Linking the United States and Africa}

A few years after its founding in New York in 1921, the AOC spread-beyond communities in the United States, Canada, and the Caribbean-to South Africa (1924), to Southern Rhodesia and Uganda (1928), and sometime later to Kenya (1935) and Ghana/Nigeria (1944). This expansion was spectacular if one bears in mind that the AOC severely lacked the money necessary for missionary activities. In fact, this spread was occasioned mainly by a secular journal: the Negro World, the press organ of UNIA, which was widely circulated in western and southern Africa.

In 1923 or 1924, McGuire joined UNIA again and became a prominent member. At the convention in 1924 he led the religious opening ceremony as primate of the AOC and held a sermon in front of thousands of participants with the title “'What Is That in Thine Hand?' The Road of Political Destiny, of Industrial and Commercial Achievement, of Financial Acquisition and of Spiritual Freedom Is in the Negro's Hands-The Road of the UNIA." 5 This was published in the Negro World on August 9 and was already being read in South Africa by September. In Kimberley, a certain Daniel William Alexander, ${ }^{6}$ archdeacon of the mission-independent African Church, came across an issue of the journal. As a result of reading the article, he decided in a series of conferences with the congregations under his leadership to end the link with the African Church 
and to found the AOC in South Africa. The foundation of the AOC was decided at a meeting on October 6,1924, when "all the congregation then declared their willingness to be under the supervision of the African Orthodox Church." The first response from the AOC in the United States, however, reached South Africa only by the end of November at the very earliest, some two months after the foundation of the AOC in South Africa.

At the end of 1924, McGuire wrote in an editorial in the AOC press organ in New York: "Within three years the East and the West have met each other in the African Orthodox Church. Without any missionary agency, the glad tidings have bridged the Atlantic through the press, and especially through the columns of The Negro World to which paper we acknowledge our thanks, and our brethren in Motherland have declared themselves freemen in the Church of the Living God." In 1927, Daniel William Alexander confirmed this statement from the South African perspective: "Having read in the Negro World in 1924 of the African Orthodox Church, I was at once inspired to write to His Grace the Archbishop."

Because of the lack of money required for transatlantic passages, the link between the AOC in the United States and the AOC in South Africa was limited to the exchange of mail. This included not only letters but also the regular exchange of the Negro Churchman - the AOC press organ from New York. From 1929 onward, the AOC in South Africa began to publish its own monthly paper, the African Orthodox Churchman, and send it to the United States. These additional forms of communication offer an answer to the question of how the AOC organizations in South Africa and the United States emerged as a transatlantic religious community, essentially sharing the same doctrine, ecclesiastical order, and liturgy, without an intensive intercontinental exchange of people. The first, and for a long time the only, visit from South Africa to the United States was paid by Alexander in 1927 for his consecration as bishop. The only visit from the United States to South Africa was made by Patriarch James I, accompanied by another American bishop, in 1960. Under these circumstances, the AOC journals helped the South African activists to adopt the specific character of the AOC and to form one church from two separate religious communities in South Africa and the United States. Such a dynamic would not have been possible only by means of letters in the absence of a more engaging medium of communication, such as the church periodicals.

Similar to the situation in South Africa, the information about the existence of the AOC in New York was brought to Uganda by the Negro World. The following autobiographical account of Ssebanja Mukasa Spartas recounts that event: "It was in 1923 [probably actually in 1924] when I came across a newspaper called 'Negro World' published by a famous man called Marcus Garvey who was in America. In that paper there was an article about the African 
Orthodox Church in America. Alleluia! Amen!"10 The author of these lines was an African teacher, serving at the time of his encounter with the Negro World as a soldier and clerk in the Fourth Regiment of the British colonial King's African Rifles in Bombo (Uganda). Acting as clerk for the intelligence office, he had access to the regiment's depot, where he found the issue of the UNIA press organ. The presence of the journal was very likely the result of confiscations and other measures enacted in order to keep emancipatory African American propaganda away from East Africa. In 1925, Spartas wrote to McGuire in New York, but he only received a response to his letter in 1928. In the aftermath of this exchange of letters, Spartas publicly announced the foundation of the AOC in Uganda on January 6, 1929, and from 1931 to 1932 Daniel William Alexander, who was the archbishop of the AOC for the African province at that time, visited this community from South Africa.

Judging by a later report by Alexander, the first information about the AOC reached Southern Rhodesia once again by means of the Negro World. In 1956 Alexander wrote the following for the daily paper the Bantu Mirror from Bulawayo (Southern Rhodesia): "In the year 1922, when the Garvey Movement was at its height, they published a Newspaper which was named 'The Negro World.' It was sold all over the world by Negro seamen, some eventually reached the Rhodesias. One of the readers Mr. John Mphamba and his friend Mr. Daniel C. Dhliwayo began to write to the late Dr. McGuire, who was at that time Chaplain-General of the UNIA."11 Even if the information about McGuire being chaplain-general of the UNIA in 1922 is not correct and the article about the AOC should consequently be dated one or two years later, it is possible that the model applied in South Africa and Uganda was repeated in the case of Southern Rhodesia. John Mphamba was one of the first activists of the AOC in this area. He was originally from Nyassaland (Malawi), spent some time in South Africa, and remained active in a network of African political activists, including members of the UNIA and of the Industrial and Commercial Union.

Dick Dube, also in Bulawayo, wrote a letter to Daniel William Alexander in South Africa in April 1929, addressing him as the "Editor of the A[frican] O[rthodox] Churchman": "Now is long time since I wrote to 142. W. 130th at New York City, USA. I received answer from them, but it was very hard that time for C[riminal] I[nvestigation] $\mathrm{D}$ [department] was troubling us because did not [allow the] I[ndustrial and] C[ommercial] U[nion] in this country." ${ }^{\prime 2}$ It is interesting that in the 1920 s various offices of the UNIA were situated at 142 W. 13oth Street in New York. Obviously, Dube regarded the AOC as an institution of the UNIA and sought contact with the AOC in South Africa as though its members were representatives of the UNIA. Furthermore, we learn from Dube's account that a second AOC activist in Southern Rhodesia was interested in the activities of the UNIA - probably as a reader of the Negro World - while at the 
same time being aware of the AOC press organ in South Africa, the African Orthodox Churchman.

Finally, in a later period the AOC came to also have a branch in West Africa. The first news about the existence of the AOC in the United States reached West Africa very probably in the 1920s through the propaganda efforts of the UNIA and Marcus Garvey. ${ }^{13}$ But the first documents referring to direct contact between the AOC and West Africa date from a later period: in 1944 Daniel William Alexander in South Africa wrote to AOC Patriarch James I in New York, expressing his optimism regarding the "promising" news from West Africa. ${ }^{14}$ Two years later, Alexander informed the South African AOC synod that the patriarch had appointed him to visit West Africa. This mission resulted from an application made by a certain Bishop Jones of the "Christian Orthodox Church" in Accra, which had requested in New York an affiliation of his church with the AOC. It is unclear if and when Alexander made his trip to West Africa, since South African sources remain quiet about this. In 1958, a synod protocol of the AOC in South Africa testifies indirectly to the existence of a branch in West Africa by including Bishop Carey H. Jones and the archpriest Michael Abradu, both from Ghana, together with a deacon and a further nine lay readers in Ghana and Nigeria on the list of the clergy. ${ }^{15}$ Two years later, Patriarch James I presumably went to West Africa after visiting South Africa. Without a detailed study of West African archives and other North American sources it is difficult at this stage to state how deep the link of the AOC branch in West Africa with the sister churches in Africa and North America has been. Nevertheless, the AOC spread without planned and sustained mission activity beyond South and East Africa also to the west of the continent, this fact being evidence for how attractive the church was in the given religious and political contexts.

To summarize: the first contact between the AOC in the United States and activists on the African continent-in South Africa, Uganda, and Southern Rhodesia-was established by means of the secular journal the Negro World. The deepening of this connection to the point that religious and political activists in such widespread territories became part of one church extends back further to the regular exchange of letters and journals.

\section{Constructing Confessional Identities:} From an "Imagined" to a "Real" Eastern Orthodoxy

One of the questions that may arise from a first encounter with the history of the African Orthodox Church concerns the name of the church. The AOC in New York was not and still is not-in spite of its name-part of Eastern or Oriental Orthodoxy. The AOC emerged in New York in 1921 among activists for 
the social and political emancipation of Afro-Americans, many of them by that time active or former members of the UNIA. In 1921, McGuire unsuccessfully approached Russian and Greek Orthodox bishops in New York to ask for his consecration. During this time he further remained an active religious leader and was the founder of a black independent denomination. But for him and his supporters to be merely "another" black denomination in the broad religious landscape of the Afro-American community was not enough. Justification for the new church was sought and found in the possession of apostolic succession. In an article titled "Our Race Needs Our Church," Bishop R. G. Grant of the AOC in the United States put it in the following way:

Do we need the African Orthodox Church? Yes, we do! First, because it has done effectively for the Negros of Episcopalian training, traditions and tendencies, what has already been done for colored Methodists by such ecclesiastical organizations as the African Methodist Episcopal Church, the A.M.E. Zion, the C.M.E. and other such Churches. ... It really has done all that is necessary to provide for its people a genuine Catholic Church free from alien domination.... It preserves intact all the formularies, traditions and customs of the ancient, primitive and undivided Church. It possesses the Historic Episcopate, it lays claim to the possession of the Apostolic Succession, and holds this claim without fear of contradiction. ${ }^{16}$

With this self-image, the AOC presented itself as a "Catholic church"-a church for all colored "Catholic people." For non-Protestant people of color, the AOC had to be what the African Methodist Episcopal Church and other black churches represented for their members. In this way, the AOC sought to bridge a gap in the black religious landscape by making itself the home of black Episcopalians and Catholics, separate from white-dominated bodies.

This self-image still does not provide an explanation for the necessity of the attribute "Orthodox" in the name of the church. "Catholic" or "Episcopal" would just as well have matched the intention of the founding fathers of the AOC. In fact, over the course of time all three attributes were used synonymously within the AOC. In comparison with the alternatives Catholic and Episcopal, however, Orthodox provided a connotation of liberation. In the United States and in Africa, Orthodoxy was not associated with white missionary paternalism or Western colonialism and imperialism. As McGuire put it, Catholic and Episcopal churches bore the burden of their association with these attitudes: "For over a quarter of a century we as Negro Churchmen, have been beseeching our white brethren to give us an opportunity to enjoy ecclesiastical freedom through the possession of a Racial Episcopate, that we 
might minister fully to the needs of our group. Often in these long years have we asked and as often have we been refused.... Such treatment we interpret to mean that our perpetual lot is to remain doorkeepers in the Holy Catholic Church. ${ }^{{ }^{17}}$ In Uganda, Spartas believed that Orthodoxy addressed the issue of authenticity: "THE CHURCH OF TRUTH WHICH HAS NEVER DEVIATED FROM CHRIST AND HIS DISCIPLES IS CALLED ORTHODOX." ${ }^{\prime 18}$ Thus by choosing "Orthodoxy," Western missionary sectarianism and white paternalism could simultaneously be avoided. At the same time, legitimate diversity and autonomy were still seen as possible following the principle of Orthodox autocephaly. Archdeacon of the AOC F. A. Garrett explained the relation between the Orthodoxy or Catholicity of the church and the plurality of churches in the following manner:

Now, as a matter of fact, the African Orthodox Church does not claim to be the Catholic Church, but simply a part of the Catholic Church. Let me give you an illustration. We have the Russian Orthodox Church, for example; and again, the Greek Orthodox Church; and still again the Syrian Orthodox Church; but none of these Churches claims to be the whole Catholic Church of Christ, but simply a part... The Greek Orthodox Church is the Church for Greek Catholics, the Russian Orthodox Church for Russian Catholics, the Syrian Orthodox Church for Syrian Catholics and the African Orthodox Church for Colored Catholics.... Any particular National or Racial Church which claims to be the whole Catholic Church of Jesus Christ is, therefore, by their own official designation mistaken... The title, therefore, which is inclusive, is the word "Orthodox" and not "African" or "Greek" or "Russian" or "Syrian." Thus, the very fact that we include the word "Orthodox" in the official title of our particular ecclesiastical organisation establishes the unity of our faith with that of the rest of the Orthodox Christendom. ${ }^{19}$

According to this view, the formation of the AOC on a principle of race-without racial discrimination or exclusivity-was legitimate in light of the traditional model of church organization in Orthodoxy while at the same time preserving the principle of necessary unity within the church. Along with the connotation of liberation, this ethnic (i.e., racial) principle of self-determination attracted the AOC activists to choosing Orthodoxy-Eastern rather than Ethiopian Orthodoxy, unlike earlier Ethiopistic churches-as their ecclesiastical model.

The formal appeal of the name does not necessarily imply the acceptance of Orthodox principles. The question regarding the kind of Orthodoxy that the AOC adopted is therefore all the more necessary, as its founding fathers in the United States were mostly former Episcopalians, whereas the AOC population 
in Africa had various Protestant and non-Protestant backgrounds. At the same time, AOC activists in the United States and Uganda had only limited knowledge of Eastern Orthodoxy, and those in South Africa had almost none. The intention of the AOC to realize Orthodoxy was, however, a genuine one and materialized in various aspects of church life. One of the most advertised such transformations-chosen in this article as an exemplary paradigm for the profile of the AOC-concerns the liturgy.

At the founding synod in New York on September 2, 1921, a commission for the creation of a new AOC liturgy was appointed. After two years' work the commission presented the text of a new "Divine Liturgy." Analysis reveals that in structure and content this liturgy was over 90 percent identical with the Roman Catholic Tridentine Mass. The few modifications that were undertaken can be traced back to Anglican or Old Catholic forms. The only Eastern influence was the omission of the filioque clause from the creed. In this spirit, the liturgy was advertised in the United States as "A Gem of Public Worship.' Both Anglican and Roman can use it profitably" ${ }^{20}$ and characterized as "perfectly Western Orthodox." ${ }^{\text {21 }}$ This change was accompanied by the introduction of other Roman Catholic liturgical forms (i.e., the rites of the seven Sacraments, the Angelus, the Office of Matins and Vespers, etc.), as well as the use of the Roman Pontifical for other rituals. In an attempt to introduce the new liturgical order, the AOC leadership made stern appeals to their congregations: "Throw into the discard your Book of Common Prayer, which you have had to use these two years. You are a disloyal Priest, and justly liable to rebuke, or worse, if you are using a Protestant Book, now that your own Liturgy is available"; ${ }^{22}$ or "Train your people up from their Protestant environment to the Catholic standards of the Undivided Church, rather than train yourselves down to conform with Reformation novelties."23

In Africa, the situation was different. In South Africa, the AOC liturgy was initially enthusiastically accepted by all the activists. Its celebration at the first synod of January 1925 brought about a sense of confessional change for those accustomed to Protestant worship forms. Soon after, however, the church leaders noticed the impossibility of generalizing the use of this liturgy because a supply of the necessary number of copies could not be assured. On the other hand, the parishes were so poor that liturgical vessels, garments, and other essential materials could not be afforded. In practice, therefore, the AOC in South Africa used existing liturgical texts, which were mostly of Protestant origin - with few exceptions-in parallel with the acknowledgment of the new liturgy. As a rule, the "Divine Liturgy" was celebrated during synods and on other occasions by Archbishop Daniel William Alexander.

In Uganda, Spartas used forms of worship inherited from Anglicanism between 1929 and 1931. From 1931 to 1932, Daniel William Alexander struggled 
to introduce the new AOC liturgical order during his visit there. A Greek Orthodox merchant in Kampala at one point observed the "Catholic" style of worship and notified Spartas of his impression. Subsequently, the merchant offered to establish contact between Spartas and a Greek Orthodox priest in the neighboring country Tanzania. Spartas became increasingly receptive to the proposal, the more he sought-in his own words-"true Orthodoxy." In the end, Spartas established contact with the Greek Orthodox Patriarchate of Alexandria. Regarding the liturgy, the account of the Greek Orthodox metropolitan Nikolaos of Axum gives a clue about the form of AOC worship in Uganda in 1942: "Their liturgy as is today, presents a paradoxical phenomenon. It has neither the Orthodox, nor the Anglican, nor the Latin [format]. It has something from everything. It is however worth admiring the effort of these people and their insistence on becoming Orthodox." ${ }^{24}$

In conclusion, the "Orthodoxy" of the AOC emerged from a combination of Anglican, Roman Catholic, and Eastern Orthodox elements. As shown by practical worship, an effort was made in the United States to implement "Catholic" standards. In South Africa, under the pressure of local conditions, worship remained basically Protestant. In East Africa (Uganda and later Kenya), worship gradually assumed an Eastern Orthodox shape. Regarding faith and church order, the AOC struggled to emphasize its Orthodoxy by removing the filioque clause, recognizing seven ecumenical councils and seven Sacraments and enforcing an Episcopal-hierarchical-structure. Under these circumstances, a hybrid confessional identity emerged-characterized in the United States as "Western Orthodoxy" but formed as well by the conditions on the ground (such as in South and East Africa). The acceptance of the AOC local churches in Uganda and Kenya by the Greek Orthodox Patriarchate of Alexandria in 1946 was an additional element of the dynamic profile of this confessional identity.

\section{Perspectives for Future Studies in World Christianity}

The final section of this article is an attempt to illustrate how the study of the AOC might contribute to scholarship on world Christianity.

\subsection{Transregional Perspectives}

In the past, the study of the AOC focused regionally on its branches in the United States or South or East Africa. Essentially, these regions were treated separately, with the interactions between them only occasionally being considered, and even then only to a small extent. In research regarding the United States and South Africa, a strong historical-sociological perspective dominated, focusing mainly on the implications of the Garvey movement in the 
religious sphere. The link between the United States and South Africa was emphasized using the biography of Daniel William Alexander and his contact with AOC head and UNIA activist George Alexander McGuire. Again, South Africa was considered generally as a case study in itself from the point of view of the historian interested in the conditions of a nonmissionary church during a time of consolidation and transformation within the Union of South Africa between the 1920s and 1946. Only the voyages of Alexander to the United States (1927-28) and to East Africa (1931-32 and 1935-37) marginally widened the narrow perspective on South Africa. Finally, East Africa (Uganda and Kenya) was examined from the perspective of the protonational movement in the British colonial context, focusing on the emergence of an education system independent from colonial and missionary interference. Occasionally, both South Africa and East Africa were considered from the perspective of Eastern Orthodox mission studies.

With this in mind, two comments must be made. First, a comprehensive understanding of the AOC can only be reached from a transregional perspective. The influence of the press on the spread of the AOC; the role of apostolic succession in the legitimization of independent churches in Ceylon, New York, and South and East Africa; the dynamic dimension of denominational identity in the transatlantic triangle of the United States and South and East Africaall these elements can only be properly addressed within a transregional and comparative perspective. As a contribution to Garvey's reception in Africa and implicit in the history of the black emancipation movement after World War I, the AOC shows-contrary to general opinion-that East Africa was touched by the influence of this movement. Second, the history of the AOC from a transregional perspective gives a clue to the official politics of independent churches in different British-dominated territories: South Africa, with its different regional traditions such as Cape liberalism in some territories and oppressive Boer politics in others; Kenya and Southern Rhodesia, as settler colonies, with their interest in suppressing every kind of African self-determination; the protectorate Uganda, where colonial power only had general control but natives enjoyed a certain freedom of action.

Furthermore, the study of the AOC not only reveals exotic forms of Christianity in the United States and various parts of Africa but also shows the unexpected links between elements that have commonly not been thought of together: for example, the apostolic succession of the Syrian Malabar Church from South India and Ceylon and church independence in North America and Africa. In the same manner, the history of the AOC reveals how impulses stemming from different sites (but not centers) were dynamically received in distant regions and led to unintended transformations: so the search for a "Western" type of Orthodoxy in the United States ended in East Africa with the admission 
of the local AOC branch to the Greek Orthodox Patriarchate of Alexandria, implying a comprehensive transformation.

\subsection{Afro-American and African Initiatives}

Such a transformation reveals the active role of indigenous people. Although the AOC may be regarded as a single church body between East Africa and New York, the different regional circumstances forced the activists to address local problems. As the example of the liturgy has shown, North American principles were impracticable in Africa and had to be adapted. All the local branches of the AOC necessarily had to follow their own agenda in response to local circumstances.

Regarding the spread of the church, Africa played a more obvious role. Money was scarce in the American headquarters. The mission of the AOC in the West Indies itself-the homeland of most of its members-was centered on the contributions of a few activists without financial assistance from the church. Under these circumstances, an African mission was practically impossible. Only the Africans' initiative, after reading the secular journal the Negro World, led to the spread of the AOC to South Africa, Southern Rhodesia, and Uganda. Later on, in 1935, Daniel William Alexander was invited to Kenya by the Kikuyu Independent School Association to help its members establish a church for those who had chosen to boycott mission churches and schools. Without African initiatives, the AOC would have never crossed the Atlantic.

\subsection{Emerging Transatlantic Non-Western Christian \\ Networks and the Role of New Media}

The AOC spread over the Atlantic without a dollar spent by the American headquarters. First, this was possible because the "seed" was sown by the secular journal of the UNIA. Second, the AOC press organs in New York (Negro Churchman, started in 1923) and in Kimberley (African Orthodox Churchman, started in 1929) essentially contributed to deepening the sense of unity among the scattered church branches. Owing to a lack of money, there were only two transatlantic visits: the first made by Daniel William Alexander to the United States between 1927 and 1928 and the second to South Africa by AOC Patriarch James I in the company of another American bishop in 1960. The unity of the AOC local branches, based on the volatile link of letters and press communication alone-without the background of a long joint history-is remarkable in itself.

Even though historians and scholars of missionary history have been particularly interested in communication media, and new media have played an important role in world Christianity in recent decades, current research-with few exceptions-has not shown any interest in the media used by indigenous 
Christians at the beginning of the twentieth century. For some reason, the existence of journals edited and owned by indigenous Christians in different parts of the world has passed unremarked. Because of the strong focus on missionary media, the question of transregional communication by indigenous Christians through modern media still has not been properly addressed. The history of the AOC represents a case study of the use of such modern media by Africans outside the sphere of Western missions.

\subsection{Reconsidering the Role of Previously Ignored \\ Denominational Traditions}

Because of an increasing focus on the role of Western missionary agents in the study of world Christianity in the nineteenth and twentieth centuries, research has essentially only concentrated on mainstream Western denominations. The abundance of studies on the work of Anglican, Baptist, Lutheran, Roman Catholic, Methodist, Reformed, Charismatic, and other missionaries-from Japan, China, and Korea to Latin America - is remarkable. In recent years, attention has been paid also to the "native helpers" of Western missions on the ground. In the shadow of these Western missionary enterprises, however, the role of many other denominational traditions was completely overlooked. Studies on Orthodox missions (important examples can be found in the Far East, in Siberia, and across America, from Alaska to California) or on Orthodox diasporas, from Australia to North America, remain to be undertaken, and the role that Eastern and Oriental Orthodox traditions play in world Christianity remains to be addressed. The early Ethiopian movement shows the role played by ancient Ethiopian Christianity as a symbol and reference point for the genesis of religious and political independence among people with African ancestry on both sides of the Atlantic. Genuine Ethiopian Orthodox churches, or those deriving inspiration from them, can be found not only on many parts of the African continent but also in the Caribbean and North America, most of them without a connection to the Ethiopian diaspora. The AOC reveals the inspiring role that Eastern Orthodoxy played in the formation of a black transatlantic religious community between 1921 and 1960.

\subsection{Dynamic Denominational Identities}

The focus of mission studies on the role of certain Western missions-such as (German) Lutherans in southern Africa, (British) Anglicans in South India, (American) Baptists in China, or (French) Catholics in the Congo-has the side effect of an overconcentration on such mainstream denominations. In spite of its Eastern Orthodox model, the AOC displays elements of a dynamic denominational identity. As a consequence, some forms of Christianity may 
not be properly understood in regard to known denominational identities, such as Catholic, Orthodox, or Episcopal ones. Moreover, they might be completely overlooked in the wake of traditional denominational studies, or inadequate research regarding their nature might lead to improper cataloging by limiting one's search to the columns of the denominational "periodic table of the elements." The AOC defined itself as "African Orthodox," "Western Orthodox," "Orthodox Catholic," and "Orthodox Episcopal" or simply as "Orthodox," "Catholic," and "Episcopal." None of these hybrid categories can be found in the laboratory of traditional denominational chemistry. Considering such a hybrid denominational identity, research on world Christianity must take note of new forms of Christian existence, as yet unknown to ecumenical studies.

\subsection{The Issue of Periodization}

Certainly, one of the most crucial aspects of a future history of world Christianity is the issue of periodization. Can there be something like a common chronological framework for the various Christian groups and agents-taking into account their specific historical experiences, different cultural and religious contexts, and the variety of regional developments? ${ }^{25}$ It is noteworthy that the AOC spread in Africa at a time when the traditional missionary churches were suffering considerable setbacks in those regions, at least temporarily. The AOC also provides a remarkable example in terms of the general history of globalization. Quite commonly, World War I has been regarded as the end of a phase of intensified globalization, followed by the interwar period, which was characterized by international disintegration and the collapse of previously established channels of global exchange. By contrast, the transatlantic network of the $\mathrm{AOC}-$ and other religious organizations with a primarily pan-African background-expanded. Interestingly, these networks emerged as a result of the activity of African and Afro-American agents, independently of Western initiatives. Generally, the growth of non-Western networks characterizes the dynamic of world Christianity in the twentieth century.

\subsection{The Modernization Paradigm}

The central narrative of Western missions linked the spread of Christianity with civilizing and modernizing the non-European world. This conceptual model must not be taken over by studies in world Christianity. The spread of Christianity in the world and the existence of world Christianity today are not identical with Western-style modernization, even if the rapid extension of some charismatic Christian forms might suggest a sense of "quasi-Westernization" or "Americanization" of evangelized territories. The AOC shows that during 
the first part of the twentieth century, the emerging indigenous form of Christianity had an independent profile vis-à-vis Western Christianity. Although elements of modern Western civilization-such as education-contributed to this, the strong hold of local customs-such as female circumcision and polygamy in East Africa-among native Christians also undoubtedly played a role. Because the extent of this article does not allow for a broad presentation of the AOC profile in Kenya, only a few introductory remarks may be made here. By the end of the 1930s, the boycotters of missionary schools and churches in Kenya turned against their former missionaries and teachers because of the missionary attempt to suppress the old custom of female circumcision. Consequently, during the first decades of the AOC's existence, its members-as well as members of other independent churches-in Kenya and Uganda were supporters of female circumcision, practiced polygamy, and took part in ritual beer drinking at tribal assemblies. The AOC did not define itself by any of the said customs, but their practice equally did not constitute a barrier to becoming a member of the church.

Similarly, in the context of colonial societies such as South Africa, Southern Rhodesia, and Kenya, modernization generally implied the destruction of traditional social forms and a suppression of self-determination in order to respond to the needs of a capitalist colonial society. In this context, modernization had a devastating impact on the indigenous population in many overseas regions, whether Christian or not. For these two reasons, the narrative of linear evolution from the "darkness" of paganism to the "light" of Christianity must be abandoned in the study of world Christianity. More correctly, one must speak of a variety of interactions between local traditional culture and the values of Western Christianity, which contributed equally to the emergence of Christianity as a world religion.

Ciprian Burlacioiu is a researcher and lecturer (Privatdozent) at the chair for Early and Global History of Christianity, Faculty of Protestant Theology, Ludwig-Maximilians-Universität München, Germany. He is a Romanian, studied Orthodox theology, and received a Ph.D. from the University of Bucharest with a dissertation on ecumenical models of church union. His habilitation thesis on the history of the African Orthodox Church between the United States, South Africa, and East Africa (1920s to 1950s) was published as a monograph in 2015. His current research deals with the meaning of migration and diaspora in the general history of Christianity and especially with a case study on the importance of migration for the development of a mission-independent Christianity in southern Africa around 1900. He teaches courses on classical subjects of church history, as well as on a wide range of topics related to the history of world Christianity. 
1. On McGuire and the beginnings of the African Orthodox Church in the United States, see also Theodore Natsoulas, "Patriarch McGuire and the Spread of the African Orthodox Church to Africa," Journal of Religion in Africa 12, no. 2 (1981): 81-104; Richard Newman, "The Origins of the African Orthodox Church," in Black Power and Black Religion: Essays and Reviews (West Cornwall, U.K.: Locust Hill Press, 1987), 83-107; Warren C. Platt, "The African Orthodox Church: An Analysis of Its First Decade," Church History 58 (1989): 474-88.

2. Negro Churchman 1, no. 2 (1923): 1.

3. Cf. Negro World, April 2, 1921, quoted in R. Newman, "The Origins of the African Orthodox Church," in The "Negro Churchman": The Official Organ of the African Orthodox Church, reprint (Millwood, N.Y.: Kraus Reprint, 1977), IX-X.

4. Negro Churchman 3, no. 1 (1925): 1-2.

5. Negro World, August 9, 1924, 9.

6. On Daniel William Alexander, see also Richard Newman, "Archbishop Daniel William Alexander and the African Orthodox Church," International Journal of African Historical Studies 16, no. 4 (1983): 615-30.

7. "Resolution Passed at a Conference Held at Beaconsfield 6/10/1924", African Orthodox Church Records 2/16, Pitts Theology Library, Emory University, Atlanta; archive hereafter cited as AOC Records.

8. Negro Churchman 2, no. 12 (1924): 2.

9. Negro Churchman 5, no. 9 (1927): 4.

10. Ssebanja Mukasa Spartas, “The Autobiography of Father Spartas Ssebanja Mukasa" (unpublished manuscript, in possession of the family, Uganda, ca. 1965), 11. Cf. also J. R. Kigongo-Dam Tabajjwa, “The Life and Work of Fr. Rev. Spartas Ssebanja Mukasa" (unpublished graduating research paper, Makerere University, Kampala, 1969/70), 7.

11. Bantu Mirror, April 28, 1956, 14.

12. Dick Dube to Daniel William Alexander, 22 April 1929, AOC Records 10/9.

13. A short note about the beginnings of the "African Orthodox Catholic Church" in Ghana and the indirect influence of the Garvey movement in this matter can be read in Robert W. Wyllie, The Spirit-Seekers: New Religious Movements in Southern Ghana (Missoula: Scholars Press, 1980), 125.

14. Cf. Alexander to the Patriarch, 30 October 1944, AOC Records 11/1.

15. Cf. Synod minutes, 1958, AOC Records 4/4.

16. Negro Churchman 5, no. 2 (1927): 5.

17. Negro Churchman 1, no. 2 (1923): 1.

18. Spartas, "Autobiography of Father Spartas Ssebanja Mukasa," 11.

19. Negro Churchman 7, no. 1 (1929): 4.

20. Negro Churchman 1, no. 11 (1923): inside front cover.

21. Negro Churchman 2, no. 3 (1924): 8.

22. Negro Churchman 2, no. 1 (1924): 8.

23. Negro Churchman 1, nos. 9-10 (1923): 2. 
24. Nikolaos of Axum, "An Appeal by Native Christians to the Patriarchate of Alexandria," in Yearbook and Review 2004, ed. Makarios Tylirides (Archbishop of Nairobi) (Nairobi: Greek Orthodox Archbishopric of Kenya and Irinoupolis), 192.

25. One of the first academic discussions in the field of church history about periodization was at the conference of the Ecumenical Association of Third World Theologians in Geneva, 1983: Lukas Vischer, ed., Towards a History of the Church in the Third World: The Issue of Periodisation (Bern: Evangelische Arbeitsstelle Oekumene Schweiz, 1985). 